\title{
AKSIOLOGI PENDIDIKAN ISLAM \\ (Penerapan Nilai-Nilai Aqidah Dalam Pembelajaran Anak Di MI)
}

\author{
Mar'atus Sholihah. ${ }^{1}$ \\ Aminullah. ${ }^{2}$ \\ Fadlillah $^{3}$ \\ IAI Al-Falah As-Sunniyyah Kencong-Jember \\ (marmarapgmi@inaifas.ac.id)
}

\begin{abstract}
Education is a powerful tool to change the world by changing the behavior of society to be better. In Islamic education, one most important thing is the education of faith or belief, because it all starts from it. Faith is the foundation of knowledge and value. Islam emphasizes how important it is to teach values to kids in primary school level and how important is the role of parents and teachers. This method is very essential to build strong values for kids so that those values which are taught from that age would last forever. This happens because kids have powerful memory to remember everything. This paper explaines the importance of teaching values to primary school students and the best methods to instill Islamic values related to "akidah" in age 7 - 13 years old by using axiology theory and trying to relate it to philosophy. Axiology is one of philosophy study which focuses on the theory of values. Its study contains about how to reach knowledge to get values in ethic, logic and aesthetic ways. The result of this paper explaines that there are some steps which can be used for teachers in primary school to educate students about values in general and about Islamic values which most of students have the foundation before from their parents.
\end{abstract}

Keywords: Islamic, education, values, primary school

\section{Pendahuluan}

Pendidikan akidah merupakan salah satu hal yang sangat fundamental di dalam ajaran Islam, serta menjadi landasan bagi seseorang dalam menjalankan ibadah dan melaksanakan amal saleh. Perlunya penerapan pendidikan akidah akhlak secara dini untuk ditumbuh kembangkan dalam kehidupan mereka, sehingga hidup dan kehidupan seseorang dapat menjadi landasan untuk berperilaku yang dapat mempunyai nilai ibadah serta beramal yang baik. Sayyid Sabiq menyatakan, "tujuan hidup menurut

\footnotetext{
${ }^{1}$ Dosen PGMI IAI Al-Falah As-sunniyyah Kencong

${ }^{2}$ Dosen BKPI IAI Al-Falah As-sunniyyah Kencong

${ }^{3}$ Dosen PAI IAI Al-Falah As-sunniyyah Kencong

Vol. I. No. Q2. Oktober 2019
}

Jurnal Auladuna |63 
pandangan Islam ialah amal saleh, berbuat kebajikan, bekerja dengan sebaik-baiknya dan menunjukkan karunia Tuhan". ${ }^{4}$

Pendidikan mengemban tugas menanamkan pandangan dunia akidah (tauhid) kepada peserta didik. Institusi yang bertanggung jawab terhadap penanaman pandangan dunia akidah (tauhid) terutama adalah keluarga dan lembaga pendidikan. ${ }^{5}$ Penanaman pendidikan akidah kepada anak bukanlah sesuatu yang mudah, diperlukan kesabaran dan ketelitian dalam menjelaskan hakikat akidah (tauhid) yang sebenarnya. Anak-anak dalam pemikirannya lebih berpikir secara rasional dan empiris, sehingga pembelajaran akidah untuk anak harus sesuai dengan keadaan dan umur mereka masing-masing. Anak-anak yang belajar akidah di madrasah ibtidaiyah membutuhkan cara yang lebih sederhana dan beragam dalam memahami akidah. Anak-anak harus dipegangi akidah sejak usia dini, karena akidah merupakan dasar dari ilmu agama Islam dan pokok dari segala perbuatan yang akhirnya berpengaruh terhadap masa depan.

Pendidikan apa pun tidak akan bisa terlepas dari filsafat, demikian halnya pendidikan akidah pada anak di madrasah ibtidaiyah. Hakikat sebuah pendidikan dapat diketahui melalui perantara ilmu filsafat, oleh karenanya, ada yang mengatakan bahwa filsafat merupakan bapaknya ilmu pengetahuan. Filsafat akan memberikan banyak hal bagaimana menyelenggarakan pendidikan dengan baik. Contoh kecil bagian ilmu filsafat dipelajari pada bidang aksiologi. Aksiologi erat kaitannya dengan nilai-nilai tauhid. Pembahasan tulisan lebih menekankan kepada nilai-nilai ketauhidan tentang bagaimana cara mendidik akidah pada anak-anak di jenjang madrasah ibtidaiyah.

\section{Pengertian Aksiologi}

Term aksiologi secara harfiah berasal dari dua kata dalam Bahasa Yunani yaitu axios yang berarti nilai dan logos yang berarti teori. Atas dasar perpaduan dua kata itu, kemudian aksiologi dimengerti sebagai teori tentang nilai. ${ }^{6}$ Definisi lain secara etimologis berasal dari kata axia; nilai, value, dan logos; perkataan, pikiran, ilmu.

\footnotetext{
${ }^{4}$ Sayyid Sabiq, Unsur-Unsur Kekuatan dalam Islam, terj. Muhammad Abadi Rathony (Surabaya: Ahmad Nabhan, 1981), hlm. 207.

${ }^{5}$ Muhammad Fauzal Adhim, Mendidik Anak Menuju Taklif (Yogyakarta: Pustaka Pelajar, 1996), hlm. 83. 168.

${ }^{6}$ Burhanuddin Salam, Logika Materil: Filsafat Ilmu Pengetahuan (Jakarta: Reneka Cipta, 1997), hlm. Jurnal Auladuna | 64

Vol. ㄱ. No. Q2. पktober 2019
} 
Definisi tersebut menyimpulkan bahwa aksiologi berarti ilmu pengetahuan yang menyelidiki hakikat nilai pada umumnya ditinjau dari sudut pandang kefilsafatan. ${ }^{7}$

Aksiologi secara sederhana berarti nilai guna, sedangkan dalam kajian filsafat, istilah aksiologi biasanya diartikan sebagai suatu bidang (filsafat) yang menyelidiki nilai-nilai (values), termasuk di dalamnya tentang tujuan memperoleh pengetahuan. Ia merupakan salah satu objek filsafat murni yang berfungsi untuk menilai hakikat sesuatu yang berkaitan dengan nilai, baik etika, logika, maupun estetika. ${ }^{8}$

Aksiologi adalah filsafat untuk mendapatkan atau menegakkan axis (sumbu) kesemestaan, atau jejer (Jawa). Wheelright mendefinisikan aksiologi sebagai cabang filsafat yang mempelajari cara-cara berbeda yang mana sesuatu bisa baik atau buruk, yaitu mempunyai akibat positif atau negatif, dan hubungan nilai-menilai di suatu pihak dan dengan fakta-fakta eksistensi objektif dari pihak lain. ${ }^{9}$

Aksiologis adalah cabang filsafat yang mempelajari cara-cara yang berbeda di mana sesuatu hal bisa baik atau buruk dan hubungan antara nilai dan menilai di satu pihak dan dengan fakta-fakta eksistensi objektif di pihak lain. Aksiologi dalam kaitannya dengan ilmu pengetahuan dapat dipahami sebagai bidang telaah terhadap ilmu yang mempertanyakan tujuan ilmu: apakah teori ilmu itu hanya merupakan penjelasan objektif terhadap realitas, atau teori ilmu merupakan pengetahuan untuk mengatasi berbagai masalah yang relevan dengan realitas bidang kajian ilmu yang bersangkutan.

Richard Bender mengungkapkan bahwa suatu nilai adalah sebuah pengalaman yang memberikan suatu pemuasan kebutuhan yang diakui atau yang menyumbangkan pada pemuasan. Kehidupan yang bermanfaat ialah pencapaian dan sejumlah pengalaman nilai yang senantiasa bertambah. ${ }^{10}$ Suriasumantri mengatakan, aksiologi adalah teori nilai yang berkaitan dengan kegunaan dari pengetahuan yang di peroleh. ${ }^{11}$

Aksiologi adalah teori tentang nilai, teori yang membahas tentang nilai, manfaat atau fungsi sesuatu yang diketahui tersebut dalam hubungannya dengan

\footnotetext{
${ }^{7}$ Ainurrakhman Hidayat, Buku Ajar Filsafat Ilmu (Pamekasan: STAIN Press, 2006), hlm. 44.

${ }^{8}$ Redja Mudyaharjo, Filsafat Ilmu Pendidikan (Bandung: Remaja Rosdakarya, 2001), hlm. 3.

${ }^{9}$ Irma Fatimah, Filsafat Islam, ed. (Yogyakarta: LESFI, 1992), hlm. 56.

${ }^{10}$ Ali Abri, Filsafat Umum Suatu Pengantar (IAIN SUSQA, tt), hlm. 33.

${ }^{11}$ S. Suriasumantri dan Jujun, Filsafat Ilmu sebuah Pengantar Populer (Jakarta: Pustaka Sinar Harapan, 1996), hlm. 234.

Vol. DI. №. QZ. Dktober 2019 
seluruh yang diketahui tersebut. Teori nilai terkait dengan jawaban atas pertanyaan seperti: nilai-nilai bagaimanakah yang dikehendaki oleh manusia dan yang dapat digunakan sebagai dasar hidupnya. ${ }^{12}$

\section{Aksiologi Pendidikan Islam}

Ajaran Islam merupakan perangkat sistem nilai, yaitu pedoman hidup secara Islami, sesuai dengan tuntunan Allah SWT. Aksiologi Pendidikan Islam berkaitan dengan nilai-nilai, tujuan, dan target yang akan dicapai dalam pendidikan Islam. Tujuan pendidikan Islam menurut Abuddin Nata adalah untuk mewujudkan manusia yang saleh, taat beribadah, dan gemar beramal untuk tujuan akhirat. Nilai-nilai tersebut harus dimuat dalam kurikulum pendidikan Islam, diantaranya: ${ }^{13}$

1. Mengandung petunjuk akhlak.

2. Mengandung upaya meningkatkan kesejahteraan hidup manusia di bumi dan kebahagiaan di akhirat.

3. Mengandung usaha keras untuk meraih kehidupan yang baik.

4. Mengandung nilai yang dapat memadukan antara kepentingan kehidupan dunia dan akhirat.

Pendidikan adalah usaha sadar yang dilaksanakan untuk melakukan perubahan menjadi yang lebih baik, sedangkan Islam adalah ajaran syarat akan nilai-nilai kebaikan yang dibutuhkan untuk menjalani hidup. Pendidikan Islam diartikan Omar sebagai proses perubahan tingkah laku individu pada kehidupan pribadinya atau masyarakat serta alam sekitar melalui proses pengajaran sebagai suatu aktifitas asasi dan proporsi di antara profesi-profesi asasi dalam masyarakat. ${ }^{14}$

Fadhil dalam Mujib menyatakan bahwa pendidikan Islam adalah upaya mengembangkan, mendorong, serta mengajak manusia untuk lebih maju dengan berlandaskan nilai-nilai yang tinggi dan kehidupan yang mulia, sehingga terbentuk pribadi yang lebih sempurna berkaitan dengan akal, perasaan, maupun perbuatan. ${ }^{15}$

\footnotetext{
${ }^{12}$ Jalaluddin, Filsafat Pendidikan Islam (Jakarta: Kalam Mulia, 2011), hlm. 132.

${ }_{14}^{13}$ Abuddin Nata, Manajemen Pendidikan (Jakata: Kencana, 2008), hlm. 2.

${ }^{14}$ Omar Mohammad Al-Toumy Al-Syaibany, Falsafah Pendidikan Islam (Jakarta: Bulan Bintang, 1979), hlm. 399.

${ }^{15}$ Abdul Mujib dan Yusuf Mudzakkir, Ilmu Pendidikan Islam ( Jakarta: Kencana, 2008), hlm. 26. Jurnal Auladuna | 66 Vol. 미. №. O2. Oktober 2019
} 
Zakiah mendefinisikan pendidikan Islam sebagai pendidikan individu dan masyarakat yang berisikan ajaran tentang sikap dan tingkah laku menuju kesejahteraan hidup. ${ }^{16}$

Komisi Pembaharuan Pendidikan Nasional (KPPN) menyatakan bahwa pendidikan agama perlu diketahui, dipahami dan diamalkan oleh manusia Indonesia agar dapat menjadi dasar kepribadian, sehingga ia dapat menjadi manusia yang taat. Tujuan pendidikan yang dirumuskan dalam GBHN sesuai dengan tujuan pendidikan Islam itu sendiri yakni meningkatkan ketakwaan kepada Tuhan Yang Maha Esa, maka pendidikan Islam pun dapat terselenggara di Indonesia. ${ }^{17}$ Peranan pendidikan secara mikro dalam pengembangan kualitas sumber daya insani adalah proses belajarmengajar; alih pengetahuan (transfer of knowledge), alih metode (transfer of methodology), dan alih nilai (transfer of value). ${ }^{18}$

Penulis menyimpulkan dari beberapa pemikiran tersebut, bahwa aksiologi pendidikan Islam merupakan suatu proses perubahan tingkah laku yang dilakukan melalui aktivitas yang dapat menanamkan nilai-nilai yang baik dan mulia sebagai bekal kehidupan manusia menjalani hidup yang lebih baik. Pendidikan Islam juga merupakan langkah pemoralisasian manusia dengan membina nilai-nilai humanitas yang berkorelasi positif dengan proses modernisasi dalam kehidupan sosial masyarakat.

\section{Pengertian Akidah}

Akidah secara etimologi diambil dari kata العَقْدِ yang artinya mengikat, penguatan, kepercayaan, berpegang diri, penetapan, keyakinan. Akidah menurut terminologinya dapat diartikan dengan:

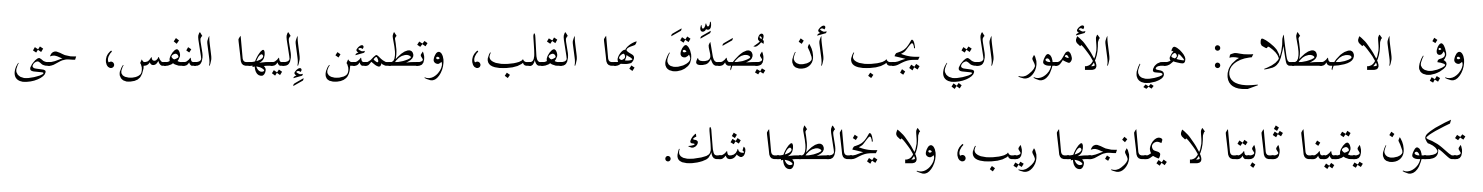

${ }^{16}$ Zakiah Daradjat, Ilmu Pendidikan Islam (Jakarta: Bumi Aksara, 2008), hlm. 28.

${ }^{17}$ Ibid., hlm. 86-88.

${ }^{18}$ Said Agil Husin Al Munawar, Aktualisasi Nilai-nilai Qur'ani Dalam Sistem Pendidikan Islam, cet. ke-2. (Ciputat: Ciputat Press, 2005), hlm. 11.

Vol. 미. №. 12 2. Uktober 2019

Jurnal Auladuna | 67 
"Akidah menurut istilah adalah perkara-perkara yang wajib dibenarkan oleh hati, dan ditanamkan dalam diri, sehingga menjadi yakin dan mengikat, yang tidak pernah tersentuh oleh keragu-raguan." ${ }^{19}$

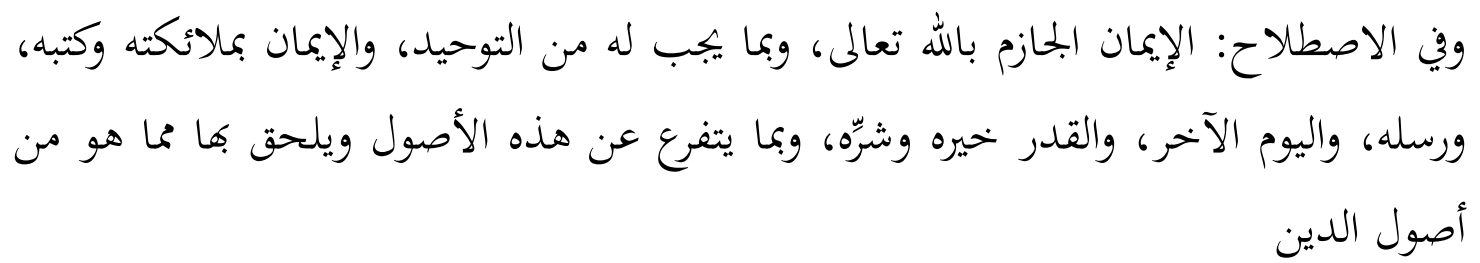

"Akidah menurut istilah adalah keimanan yang mengikat kepada Allah, dan apa yang wajib baginya, meliputi tauhid, keimanan kepada malaikatNya, kitab-kitabNya, Rasul-RasulNya, dan hari akhir, dan qada qadharNya yang baik dan buruk, dan hal-hal bercabang, yang dianalogikan dengan prinsip-prinsip dasar ini. ${ }^{20}$

Sumber akidah Islam hanya dua saja: Al-Qur'an dan Hadits Mutawatir, yakni hadits yang diriwayatkan oleh banyak orang yang tidak mungkin mereka sepakat untuk berdusta dalam meriwayatkan hadits itu. Pengertian ini bermakna bahwa akidah mempunyai sifat keyakinan dan kepastian, sehingga tidak mungkin ada peluang bagi seseorang untuk meragukannya. Pencapaian tingkat keyakinan ini menekankan bahwa akidah Islam wajiblah bersumber pada dua warisan tersebut yang tidak ada keraguan sedikit pun bahwa ia diketahui dengan pasti berasal dari Nabi, artinya: datangnya wurud, atau sampainya kepada kita diketahui dengan pasti qath'i dari Nabi.

Indikasinya dalalah juga harus pasti, dengan kata lain, untuk menjadi sumber akidah, maka asalnya dan indikasinya haruslah pasti dan meyakinkan, tidak mengandung sebarang keraguan. Al-qur'am dipandang dari segi wurud, maka ia adalah pasti meyakinkan karena telah ditulis selagi Rasulullah masih hidup dan juga dihafal serta diriwayatkan oleh sejumlah besar sahabat yang mustahil mereka sepakat berdusta untuk memalsukannya. Perselisihan pun tidak pernah timbul tentang kesahihan dan keaslian Al-Qur'an dalam kalangan umat Islam sejak dahulu hingga sekarang. ${ }^{21}$

Akidah Islam berpangkal pada keyakinan "tauhid" yaitu keyakinan tentang wujud Allah, Tuhan Yang Maha Esa, tidak ada yang menyekutui-Nya, baik dalam zat,

\footnotetext{
${ }^{19}$ Abdullah ibn Abdul Hamid al-Atsari, al-Wajiz fi 'Aqidah al-Salaf al-Shalih (Arab Saudi: Wizarah alSyu'un al-Islamiyyah wa al-Auqaf wa al-Da'wah wa al-Irsyad, 1422), hlm. 24.

${ }^{20}$ Abdullah ibn Abdul Aziz ibn Humadah al-Jabarain, Mukhtashar Tashil al-Aqidah al-Islamiyyah (tt: Maktabah al-Rusyd, $1424 \mathrm{H}$ ), hlm. 3. Bandingkan dengan: Muhammad Ahmad Muhammad Abdul Qadir Khalil Malkawi, Aqidah al-Tauhid fi al-Qur'an al-Karim (tt: Maktabah Dar al-Zaman, 1985), hlm. 20.

${ }^{21}$ Ahmad Daudy, Kuliah Akidah Islam (Jakarta: Bulan Bintang, 1997), hlm. 23. Jurnal Auladuna | 68

Vol. ㅁ․ No. 02. Oktober 2019
} 
sifat-sifat maupun perbuatan-perbuatanNya. Akidah Islam pada masa hidup Rasulullah s.a.w., diajarkan berdasarkan wahyu yang diterimanya dari Allah yang dituangkan dalam Al-Qur'an. Al-Qur'an mengajarkan agar manusia mengarahkan perhatiannya kepada alam sekitarnya, dibangkitkan akal manusia untuk memikirkan bukti-bukti kebesaran Allah dengan adanya alam raya. Hati nurani manusia yang bertabiat condong kepada hidup beragama itu dibangunkan, hingga benar-benar dapat dirasakan adanya kekuatan di luar alam, yang menjadi sumber wujud, yaitu Allah, Tuhan yang mencipta dan memelihara seru sekalian alam. ${ }^{22}$

Perkataan tauhid berasal dari bahasa Arab, masdar dari kata wahhadayuwahhidu. Arti kata tauhid dari segi etimologi berarti keesaan, maksudnya iktikad atau keyakinan bahwa Allah SWT adalah Esa; Tunggal; Satu. Pengertian ini sejalan dengan pengertian tauhid yang digunakan dalam bahasa Indonesia, yaitu "keesaan Allah"; mentauhidkan berarti "mengakui keesaan Allah; mengesakan Allah", ${ }^{23}$

Tauhid dalam bahasa Arab berarti beriman pada ke-Esaan Allah SWT., al-iman bi wahdaniyatillah atau monotheism. Iman berarti pengetahuan (knowledge), percaya (belief, faith), dan yakin tanpa bayangan keraguan (to be convinced beyond the least shadow of doubt). Pengertian iman jika ditarik kesimpulannya adalah kepercayaan yang teguh yang timbul akibat pengetahuan dan keyakinan. Orang yang mengetahui dan percaya secara mantap pada Allah SWT., disebut sebagai Mukmin. Rasa iman ini akan menuntun orang tersebut untuk bersikap taat, tunduk, patuh, pasrah, dan takwa kepada Allah SWT. Orang dengan karakteristik seperti ini disebut sebagai Muslim. ${ }^{24}$

\section{Pengertian Nilai-nilai Akidah Dalam Pendidikan Islam}

Istilah kebudayaan mengartikan nilai-nilai sebagai konsep abstrak dan bernilai dalam kehidupan manusia. ${ }^{25}$ Nilai adalah suatu kualitas tetentu yang mempunyai keberhargaan yang harus diapresiasikan dan dimiliki manusia, baik individu maupun

\footnotetext{
${ }^{22}$ A. Azhar Basyir, Pendidikan Agama Islam I (Aqidah) (Yogyakarta: FH UII, 1995), hlm. 39.

${ }^{23}$ Tim Penyusun Kamus, Kamus Besar Bahasa Indonesia, cet. ke-2 (Jakarta: Departemen Pendidikan dan Kebudayaan, 1989), hlm. 1.

${ }^{24}$ Abd. Rachman Assegaf, Filsafat Pendidikan Islam: Paradigma Baru Pendidikan Hadhari Berbasis Integratif-Interkonektif (Yogyakarta: Rajawali, 2011), hlm. 38.

${ }^{25}$ Departemen Pendidikan dan Kebudayaan, Kamus Besar Bahasa Indonesia (Jakarta: Balai Pustaka, 1990), hlm. 615.

Vol. ㅁ. No. Q2. Oktober 2019

Jurnal Auladuna | 69
} 
sosial. Nilai tersebut bersifat normatif, objektif, dan universal. ${ }^{26}$ Paul Edwards dalam bukunya The Encyclopedia of Phylosophy, nilai dibagi menjadi tiga bentuk. Pertama, nilai yang digunakan sebagai kata benda abstrak. Pengertian yang lebih sempit seperti baik, menarik, dan bagus. Kedua, nilai sebagai kata benda konkret, contohnya ketika kita berkata sebuah nilai atau nilai-nilai, ia seringkali dipakai untuk merujuk kepada sesuatu yang bernilai, seperti nilainya, nilai dia, dan sistem nilai dia. Maksud dari pengertian ini bahwa nilai konkret adalah nilai yang melekat sendiri pada suatu benda hingga ia dapat dikatakan bernilai. Ketiga, nilai sebagai kata kerja, di mana hal tersebut tercermin dari aktivitas atau ekspresi menilai, memberi nilai dan dinilai. ${ }^{27}$

Pandangan Young, nilai diartikan sebagai asumsi-asumsi yang abstrak dan sering tidak disadari tentang hal-hal yang benar dan hal-hal yang penting, sedangkan Green memandang nilai sebagai kesadaran yang secara relatif berlangsung dengan disertai emosi terhadap objek, ide, dan perseorangan. ${ }^{28}$ Louis O. Katstoff berpendapat bahwa nilai terbagi menjadi dua: nilai intrinsik dan nilai instrumental. Nilai instrinsik meniscayakan bahwa sebuah objek fakta telah terkandung di dalamnya secara permanen sebagai sebuah nilai. Nilai tersebut bisa baik atau buruk, benar atau salah, bahaya atau berguna dan lainnya. Nilai instrumental adalah lebih kepada bagaimana fakta yang ada diarahkan kepada sebuah nilai. Pisau misalnya akan memiliki nilai baik atau buruk tergantung bagaimana menggunakannya. ${ }^{29}$

Karakteristik-karakteristik nilai yang berkaitan dengan teroi nilai, antara lain:

1. Nilai objektif atau subjektif. Nilai itu objektif jika ia tidak bergantung pada subjek atau kesadaran yang menilai. Nilai subjektif bersifat sebaliknya, jika eksistensinya, maknanya, dan validitasnya tergantung pada reaksi subjek yang melakukan penilaian, tanpa mempertimbangkan apakah ini bersifat psikis atau fisik.

2. Nilai absolut atau berubah. Suatu nilai dikatakan absolut atau abadi, apabila nilai yang berlaku sekarang sudah berlaku sejak masa lampau dan akan berlaku serta absah sepanjang masa, serta akan berlaku bagi siapapun tanpa memperhatikan ras,

\footnotetext{
${ }^{26}$ M. Suyudi, Pendidikan Dalam Perspektif Al-Qur'an (Yogyakarta: 2005), hlm. 185.

${ }^{27}$ Syahridho dan Sutarman, Aliran-aliran Filsafat (tt), hlm. 216.

${ }^{28}$ Ibid.

${ }^{29}$ Ibid.
} 
maupun kelas sosial. Pihak lain ada yang beranggapan bahwa semua nilai relatif sesuai dengan keinginan atau harapan manusia. ${ }^{30}$

Pandangan-pandangan yang berkaitan dengan tingkatan/ hierarki nilai yaitu:

1. Kaum Idealis. Mereka berpandangan secara pasti terhadap tingkatan nilai, dimana nilai spiritual lebih tinggi daripada nilai non spiritual (niai material).

2. Kaum Realis. Mereka menempatkan nilai rasional dan empiris pada tingkatan atas, sebab membantu manusia menemukan realitas objektif, hukum-hukum alam dan aturan berfikir logis.

3. Kaum Pragmatis. Menurut mereka, suatu aktivitas dikatakan baik seperti yang lainnya, apabila memuaskan kebutuhan yang penting, dan memiliki nilai instrumental. Mereka sangat sensitif terhadap nilai-nilai yang meghargai masyarakat. ${ }^{31}$

Nilai-nilai yang terkandung dalam Al-Qur'an merupakan nilai-nilai yang bersifat universal karena hakikatnya, Islam adalah rahmatan lil 'alamin, maka dibutuhkan penggalian dan penyelaman terhadap kandungannya sehingga dapat diambil mutiara-mutiara Islami sebagai bekal landasan hidup manusia yang bisa membawa kesejahteraan bagi umat Islam khususnya, dan manusia pada umumnya.

Nilai-nilai akidah dalam pendidikan Islam merupakan suatu kualitas ketauhidan/ keimanan kepada Sang Pencipta, Allah Ta'ala yang dimiliki manusia setelah dia mengenal Tuhannya yang berkaitan antara hubungan manusia itu sendiri dengan Allah SWT.

\section{Hubungan Antara Aksiologi dengan Nilai-nilai Aqidah Pada Anak di Madrasah Ibtidaiyah}

Unsur seni mendidik ini dibangun atas asumsi bahwa dalam diri manusia ada aspek-aspek lahiriah, psikologis dan rohaniah. Pernyataan ini mengisyaratkan bahwa manusia dalam fenomena pendidikan adalah paduan antara manusia sebagai fakta dan manusia sebagai nilai. Setiap manusia memiliki nilai tertentu, sehingga situasi pendidikan memiliki bobot nilai individual, sosial dan moral. Pendidikan dalam

\footnotetext{
${ }^{30}$ Uyoh Sadulloh, Pengantar Filsafat Pendidikan (Bandung: Penerbit Alfabeta CV, 2007), hlm. 38-39.

${ }^{31}$ Ibid. hlm. 39-40.

Vol. ㅁ․ No. Q2. Oktober 2019

Jurnal Auladuna | 71
} 
prakteknya adalah fakta empiris yang syarat nilai. Interaksi manusia dalam pendidikan tidak hanya timbal balik dalam arti komunikasi dua arah, melainkan harus lebih tinggi mencapai tingkat manusiawi. Intinya untuk mencapai tingkat manusiawi itulah pendidikan bergerak menjadi agen pembebasan dari kebodohan untuk mewujudkan nilai peradaban manusiawi.

Aspek-aspek tersebut diperlukan untuk mencerdaskan bangsa. Kecerdasan itu dapat diperoleh jika lembaga pendidikan menggali dan menyelami nilai-nilai yang diajarkan dalam Al-Qur'an dengan cara mengaktualisasikan nilai-nilai Qur'ani ke dalam pribadi individu dan masyarakat. Pengaktualisasian tersebut membutuhkan landasan aksiologis dalam pendidikan agar pendidikan itu sendiri dapat memberikan kepuasan pada diri peserta didik akan nilai- nilai ideal yang ingin dimiliki, sehingga dapat hidup dengan baik dan terhindar dari nilai- nilai yang tidak diinginkan. ${ }^{32}$

Semua tujuan tersebut dapat ditempuh dengan cara memberikan landasan Islam pada aksiologis pendidikan. Ajaran-ajaran Islam yang tertuang dalam aksiologi pendidikan Islam diharapkan mampu membawa manusia menuju kesejahteraan hidupnya, sehingga dua perannya sebagai pemakmur kehidupan di muka bumi dan pengabdi kepada Sang Khalik dapat terlaksana dengan baik. Kedua peran tersebut tidak hanya memerlukan profesionalitas semata, tetapi juga sarat dengan nilai-nilai pengabdian kepada Allah SWT.

Pendidikan agama dan akhlak dalam Pendidikan Nasional diatur oleh UndangUndang Nomor 2 Tahun 1989 Bab IX butir 2 yang mengatakan tentang isi kurikulum setiap jenis, jalur dan jenjang pendidikan wajib memuat pendidikan Pancasila, pendidikan agama dan pendidikan kewarganegaraan. Pendidikan agama disini diartikan sebagai pendidikan yang materinya berkaitan dengan keimanan, ketakwaan, akhlak dan ibadah kepada Tuhan.

Alasan dari itu adalah Islam memandang bahwa tujuan kemanusiaan syarat akan nilai dan moral, maka memfungsikan madrasah ibtidaiyah merupakan usaha aplikatif kolektif untuk mewujudkan penumbuh kembangan perilaku moral peserta

\footnotetext{
${ }^{32}$ Abdul Mujib, et al., Ilmu Pendidikan Islam, cet. ke-. (Jakarta: Kencana, 2008), hlm. 127-128. Jurnal Auladuna | 72

Vol. ㅁ. No. O2. Uktober 2019
} 
didik yang hendaknya menjadi orientasi bagi setiap aktivitas pendidikan. ${ }^{33}$ Pendidikan moral harus berlangsung di madrasah ibtidaiyah setiap waktu, tidak hanya dalam kurikulum, tetapi juga dalam interaksi sehari-hari antara siswa dengan guru maupun staf sekolah. Sekolah-sekolah yang berusaha menerapkan nilai kejujuran melalui program "Kantin Kejujuran" turut memberikan contoh kepada madrasah ibtidaiyah sebagai sekolah yang bernuansa Islami. Penulis menganggap hal tersebut sebagai langkah yang amat baik sebagai tindak lanjut terhadap harapan-harapan pendidikan yang ingin dicapai lepas dari efektif tidaknya perubahan tersebut.

Penganggulangan yang dilakukan melalui pendidikan diharapkan dengan penanaman nilai-nilai akidah sejak dini di tingkat madrasah ibtidaiyah, sehingga mampu menjadikan manusia bertahan menghadapi laju perkembangan dunia tanpa mengabaikan kebaikan akhlak dalam mencapai ketenangan hidupnya.

\section{Penerapan Nilai-nilai Akidah Pada Anak di Madrasah Ibtidaiyah}

Faktor pendidikan bagi terbentuknya tauhid dan iman kepada Allah SWT., merupakan inti dari pendidikan Islam, sedemikian pentingnya sehingga Nabi Muhammad SAW., menyatakan: "Barangsiapa tambah ilmunya tapi tidak tambah petunjuknya (imannya), maka bagi Allah SWT., orang tersebut tidak tambah apa pun kecuali semakin jauh (dari petunjuk dan iman kepada-Nya)”. Pilar pendidikan berintikan tauhid dan keimanan ini menjadikan manusia mampu memadukan antara fungsi akal dengan wahyu. Manusia ketika telah mampu menembus ke ruang angkasa dan menginjakkan kakinya di bulan, ia tidak sekadar berhasil menguak rahasia alam atau eksploitasi sumber daya alam, melainkan berhasil pula menambah iman kepada Allah SWT. Iman menuntun ilmu agar tidak digunakan untuk kepentingan pribadi, apalagi merusak.

Seseorang dalam menegakkan tauhid pada dirinya harus menyatukan antara iman dan amal, konsep dan pelaksanaan, pikiran dan perbuatan, serta teks dan konteks, dengan demikian, bertauhid adalah meng-Esa-kan Allah SWT., artinya yakin dan percaya kepada Allah SWT., semata melalui pikiran dan membenarkan dalam hati,

${ }^{33}$ Muhmidayeli, Moralitas Kependidikan: Suatu Telaah Filsafat Pendidikan Islam Tentang Arah Bangun Pendidikan Islam, vol. 5. (Al-Fikra, 2006), hlm. 11.

Vol. ㅁ. №. 12. Uktober 2019

Jurnal Auladuna | 73 
mengucapkan dengan lisan, dan mengamalkan dengan perbuatan. Seseorang sudah dinyatakan beriman dan bertakwa apabila sudah mengucapkan kalimat tauhid dalam syahadat. ${ }^{34}$

Keimanan juga merupakan salah satu landasan pendidikan. Alasannya; pertama, keimanan terhadap suatu hal dibuktikan dengan pengakuan bahwa sesuatu itu merupakan kebenaran dan keyakinan, karenanya dia tidak lagi mengkhawatirkan adanya perkara lain yang akan mengotori hatinya. Kedua, jika keimanan seseorang telah kuat, segala tindak-tanduk orang itu akan didasarkan pada pikiran-pikiran yang telah dibenarkan dan hatinya pun akan merasa tenteram. Perilakunya senantiasa didasarkan pada landasan yang kokoh dan kuat, sehingga dapat dijadikan pegangan dan tumpukan ketenteraman. Ketiga, keimanan yang di dalamnya terdapat pembenaran dan keyakinan, kadang-kadang, dijalankan secara tidak tepat. Contoh dalam beberapa bentuk kepercayaan, misalnya Animisme, keyakinan terhadap sesuatu dibangun atas dasar khurafat atau dongeng-dongeng. Keempat, melalui ketundukan perilaku, jalan hidup, dan hubungan antar individu pada keimanan yang sahih, kehidupan kelompok individu pun akan teratur dan istiqomah. ${ }^{35}$

Pembelajaran akidah perlu mengenalkan terlebih dahulu sendi-sendi akidah Islam agar peserta didik mengetahui konsep dari akidah tersebut. Sendi-sendi akidah Islam di sebut juga dengan rukun iman, yang mencakup: ${ }^{36}$

1. Iman kepada Allah

Beriman kepada Allah adalah dasar pokok ajaran Islam. Persoalan-persoalan dalam ajaran Islam dapat dipecahkan dengan kunci iman kepada Allah. Masalahmasalah iman kepada Allah harus mendapat perhatian sepenuhnya. Pembicarakan iman kepada Allah memuat hal-hal yang esensial, yaitu; wujud Allah, ke Esaan Allah, dan sifat-sifat Allah.

2. Iman kepada Malaikat Allah

Iman kepada malaikat merupakan sebuah kewajiban yang harus diyakini oleh setiap muslim, di antara sekian banyak ayat-ayat Al-qur'an yang menyebut

${ }^{34}$ Abd. Rachman Assegaf, Filsafat Pendidikan Islam: Paradigma Baru Hadhari Berbasis IntegratifInterkonektif ..., hlm. 40 .

${ }^{35}$ Ibid. 84.

${ }^{36}$ A. Azhar Basyir, Pendidikan Agama Islam I (Aqidah)..., hlm. 42. Jurnal Auladuna | 74

Vol. DI. No. Q2. Oktober 2019 
malaikat, terdapat ayat-ayat yang secara tidak langsung memerintahkan untuk beriman kepada adanya malaikat-malaikat Allah, misalnya yang disebut dalam Surat Al-Baqarah (2): 285 yang berbunyi:

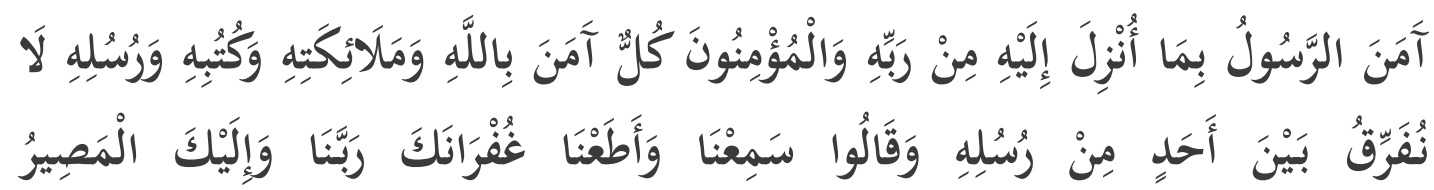

Artinya: "Rasul telah beriman kepada Al Qur'an yang diturunkan kepadanya dari Tuhannya, demikian pula orang-orang yang beriman. Semuanya beriman kepada Allah, malaikat-malaikatNya, kitab-kitabNya dan rasul-rasulNya. (mereka mengatakan): "Kami tidak membeda-bedakan antara seseorang pun (dengan yang lain) dari rasul-rasulNya", dan mereka mengatakan: "Kami dengar dan Kami taat." (mereka berdoa): "Ampunilah Kami Ya Tuhan Kami dan kepada Engkaulah tempat kembali."

3. Iman kepada kitab-kitab Allah

Kitab yang dimaksud ialah kitab yang berisi syariat, perintah, firman, petunjuk Allah yang menyinari jalan kehidupan manusia serta menentukan kewajiban manusia yang menyangkut perkara halal, haram, perintah, larangan, ibadah, dan hal-hal lain yang hendak diajarkan Allah kepada hamba-Nya. ${ }^{37}$

4. Iman kepada rasul-rasul Allah

Rasul-rasul Allah adalah orang yang dipilih Allah menjadi utusanNya untuk menyampaikan petunjuk-petunjukNya kepada umat manusia yang berupa pedomanpedoman yang akan membawa mereka memperoleh kebahagiaan hidup di dunia dan di akhirat. Al-Qur'an Surat an-Nisa' (4: 164), Allah menyatakan bahwa tidak semua para rasul itu diceritakan Allah kepada Nabi Muhammad dan hanya sebanyak 25 orang saja yang disebutkan namanya dalam Al-Qur'an dan juga yang wajib diketahui dan diimani. Lima orang di antara mereka diberi gelar sebagai Ulul 'Azmi, yaitu Nabi Nuh, Nabi Ibrahim, Nabi Musa, Nabi Isa, dan Nabi Muhammad SAW. Gerakan ini diberikan Allah kepada mereka sebagai pertanda bahwa mereka adalah pejuang-pejuang agung yang memiliki semangat kuat dan himmah tinggi

${ }^{37}$ Abdurrahman An Nahlawi, Pendidikan Islam di Rumah, Sekolah dan Masyarakat (Jakarta: Gema Insani Press, 1995), hlm. 84.

Vol. ㄱ. No. QZ. Oktober 2019

Jurnal Auladuna | 75 
serta kesabaran yang tangguh dalam berdakwah, memanggil umatnya beriman kepada Allah dan menyembah-Nya semata, tidak mempersekutukan-Nya dengan sesuatu apa pun. Suatu hadits yang diriwayatkan oleh Marwadawaih dalam tafsirnya dari Abu Dzar al-Ghifari disebutkan bahwa jumlah para rasul adalah 313 atau 315 orang, sedangkan jumlah para nabi adalah 124.000. Wallahu a'lam. ${ }^{38}$

5. Iman kepada hari akhir

Maksud hari akhir ialah berakhirnya alam kita sekarang. Sesuatu yang ada di alam menjadi binasa. Semua yang hidup dimatikan, segala sesuatu binasa, kecuali Dzat Allah, kemudian Allah menjadikan alam lain. Manusia yang telah mati dibangkitkan menjadi hidup kembali, kemudian Allah memperlihatkan perhitungan amal perbuatan tiap-tiap orang, yang baik maupun yang buruk. Neraca dibuat untuk mengetahui amal mana yang lebih berat, yang baik ataukah yang buruk untuk menentukan tempatnya.

6. Iman kepada takdir (qada dan qadar)

Takdir adalah ketetapan dan ketentuan Allah yang mencakup qada dan qadar. Qada Allah adalah kehendak atau ketetapan hukum Allah terhadap sesuatu itu, sedangkan Qadar mengandung pengertian untuk menentukan ukuran, susunan dan aturan terhadap sesuatu. Pengertian ini bisa diartikan sebagai ketentuan Allah tentang hukum sebab-akibat yang berlaku bagi segala yang berwujud, baik makhluk-makhluk hidup maupun benda-benda mati, dengan demikian, bila mengatakan bahwa segala sesuatu terjadi dengan qada dan qadar Allah, berarti bahwa segala sesuatu itu terjadi dengan kehendak dan ketetapan hukum Allah yang telah ditentukan sebelumnya dan berjalan sesuai dengan aturan yang dibuat oleh kehendak Allah di bawah pengetahuan Allah pula.

Kesimpulan yang dapat diambil dari penjabaran keenam rukun iman, bahwa pendidikan akidah merupakan pendidikan yang harus diberikan pada anak sedini mungkin karena pendidikan akidah merupakan pendidikan dasar pertama yang harus diberikan pada seorang anak agar dia mengenal dan beriman kepada Tuhannya sejak masa pertumbuhan di umur jenjang madrasah ibtidaiyah, karena akidah adalah fondasi

${ }^{38}$ Ahmad Daudy, Kuliah Akidah Islam..., hlm. 116. 
yang kokoh bagi bangunan peradaban Islam. Kekuatan peradaban yang bangun akan goyah tanpa akidah yang tertanam, dan tugas menanamkan dan menerapkan akidah adalah tugas setiap keluarga muslim kepada anak-anak mereka. Madrasah Ibtidaiyah bisa mengenalkan hal ini, tetapi, penanam yang paling kuat dan lebih utama adalah orang tua. Peran orang tua yang memilih kedekatan emosional akan jauh lebih efektif dibandingkan siapa pun (seharusnya).

Penerapan pembelajaran akidah dan menanamkannya ke dalam pikiran bukan pekerjaan seketika, butuh waktu dan kesabaran. Akidah adalah masalah yang abstrak, sedangkan anak usia 7 tahun dan seterusnya, berpikir dengan cara yang konkrit karena sel-sel syarafnya belum terkoneksi semuanya. Rasulullah memeritahkan untuk mengajarkan sholat pada anak usia 7 tahun. Sholat adalah bagian ibadah. Ibadah yang adalah salah satu implementasi aqidah bagi anak-anak memerlukan nalar yang lebih sulit, tetapi penanaman sejak awal, meski pada awalnya mereka belum mengerti, mereka akan mencernanya kelak. Keharusan yang paling penting adalah saat orangtua mengenalkan, membicarakan, menguatkan, menjadikan ini sebagai topik di rumah, secara berulang, insyaAllah ini akan terinstal di alam bawah sadar anak, jika menjadi informasi yang sudah tersimpan di alam bawah sadar, insyaAllah sampai anak ini mati tidak mudah hilang dalam pikirannya.

Periode ini anak menjadi lebih siap untuk belajar secara teratur. Ia mau menerima pengarahan lebih banyak dan lebih siap menyesuaikan diri dengan temanteman sepermainannya. Periode ini dapat dikatakan anak lebih mengerti dan lebih semangat untuk belajar serta memperoleh keterampilan-keterampilan, karenanya ia bisa diarahkan secara langsung. Masa ini termasuk masa yang paling penting dalam pendidikan dan pengarahan anak. Peran paling strategis dalam menanamkan pandangan dunia tauhid dipegang oleh guru. Seorang guru harus memahami ilmu berbicara dalam menyampaikan sendi-sendi akidah kepada siswanya. ${ }^{39}$

${ }^{39}$ Muhammad Fauzil Adhim, Mendidik Anak Menuju Taklif..., hlm. 87.

Vol. I. No. Q2. Uktober 2019

Jurnal Auladuna | 77 
Penerapannya dengan cara anak dibiasakan membicarakan tentang aspek-aspek terpenting dalam akidah, yang perlu diperhatikan oleh para pendidik pada periode ini yaitu: ${ }^{40}$

1. Pengenalan Allah dengan cara sederhana

Periode ini merupakan periode di mana guru mengenalkan kepada anak tentang Allah Azza Wajalla melalui cara yang sesuai dengan pengertian dan tingkat pemikirannya. Guru mengajarkan kepadanya: Bahwa Allah Esa, tiada sekutu bagiNya, bahwa Dialah pencipta segala sesuatu, pencipta langit, bumi, manusia, hewan, pohon-pohonan, sungai, dan lain-lainnya.

Pendidik dapat memanfaatkan situasi tertentu untuk bertanya kepada anak, misalnya ketika berjalan-jalan di taman atau padang, tentang siapakah pencipta air, sungai, bumi, pepohonan dan lain-lainnya, untuk menggugah perhatiannya kepada keagungan Allah. Cinta kepada Allah, dengan ditunjukkan kepadanya nikmatnikmat yang dikaruniakan Allah untuknya dan untuk keluarganya. Anak bisa ditanya: "Siapakah yang memberimu pendengaran, penglihatan dan akal? Siapakah yang memberi rezeki dan makanan untukmu dan keluargamu?"

2. Pengajaran tentang hukum-hukum Islam yang paling dasar

Guru mengajarkan kepada anak menutup aurat, berwudhu, hukum-hukum thaharah (bersuci) dan pelaksanaan shalat. Guru seharusnya juga melarang dari halhal yang haram, dusta, adu domba, mencuri dan melihat kepada yang diharamkan Allah. Guru meminta anak untuk mengikuti syari'at Allah sebagaimana orang dewasa dan dicegah dari apa yang dilarang sebagaimana orang dewasa, sehingga anak akan tumbuh seperti demikian dan menjadi terbiasa. Seorang anak bila semenjak kecil sudah dibiasakan dengan sesuatu, maka jika sudah dewasa akan menjadi kebiasaannya.

3. Pengajaran baca al-Qur'an

Al-Quran adalah jalan lurus yang tidak mengandung suatu kebathilan apapun, maka amat baik jika anak dibiasakan membaca al-Qur'an dengan benar dan diupayakan semaksimalnya agar menghafal al-Qur'an atau sebagian besar darinya

${ }^{40}$ M. Noor Fuady dan Ahmad Muradi, Pendidikan Akidah Berbasis Keluarga (Banjarmasin: Antasari Press, 2012), hlm. 120.

Jurnal Auladuna |78

Vol. 미. No. 02. Iktober 2019 
dengan diberi dorongan melalui berbagai cara. Orang tua hendaklah berusaha agar putra putrinya masuk pada salah satu sekolah yang mengajarkan ilmu tentang kajian al-Qur'an, seperti madrasah ibtidaiyah, di mana siswa tidak hanya diajarkan menghafal beberapa ayat dalam al-Qur'an, namun juga diajarkan bagaimana cara mengamalkan kandungannya. Diriwayatkan:

“Barang siapa membaca al-Qur'an dan mengamalkan kandungan isinya, niscaya Allah pada hari kiamat mengenakan kepada kedua orang tuanya sebuah mahkota yang cahayanya lebih indah dari pada cahaya matahari di rumah-rumah dunia. Maka apa pendapatmu tentang orang yang mengamalkan hal ini?" (HR. Abu Daud)

4. Pengajaran tentang hak-hak kedua orang tua

Guru mengajarkan kepada anak untuk bersikap hormat, taat dan berbuat baik kepada kedua orang tua, sehingga terdidik dan terbiasa demikkian. Anak sering bersikap durhaka dan melanggar hak-hak kedua orang tua disebabkan karena kurangnya perhatian orang tua dalam mendidik anak dan tidak membiasakannya berbuat kebaikan sejak dini.

5. Pengenalan tokoh-tokoh teladan dalam Islam

Tokoh teladan kita yang utama yaitu Rasulullah SAW., kemudian para sahabat yang mulia R.A., dan penggikut mereka dengan baik dan menjadi contoh terindah dalam segala aspek kehidupan. Guru disarankan memperkenalkan kepada anak tentang mereka, diajarkan sejarah dan kisah mereka supaya meneladani perbuatan agung mereka dan mencontoh sifat baik mereka seperti keberanian, keprajuritan, kejujuran, kesabaran, kemuliaan, keteguhan pada kebenaran dan sifatsifat lainnya.

Kisah atau kejadian yang diceritakan kapada anak hendaklah sesuai dengan tingkat pengertiannya, tidak membosankan, dan difokuskan pada penampilan serta penjelasan aspek-aspek yang baik saja, sehingga mudah diterima oleh anak. Guru bisa menceritakan kepada anak kisah Rasulullah bersama orang Yahudi yang menuntut kepada beliau agar membayar uang pinjamannya, sebagai contoh akhlak baik beliau. Sejarah umat Islam penuh dengan tokoh-tokoh agung dan kisah-kisah menarik yang menunjukkan keutamaan dan makna yang indah. 
Penerapan dengan menanamkan akidah pada jiwa anak sangatlah di prioritaskan agar terbentuklah jiwa dan sikap hidup manusia yang hanya percaya dan yakin pada Allah, serta menjadikannya keindahan pokok atau pedoman hidup dalam tindak tanduk manusia hingga mereka tidak akan kehilangan arah. Contoh yang bisa dijadikan pedoman adalah cerita Lukman Hakim yang menanamkan pendidikan akidah sebagai urutan pertama terhadap buah hatinya, dengan demikian, pendidik harus bisa memiliki kualitas iman yang kokoh dan pemaaf, karena dia akan menjadi figur bagi anak didiknya. Pendidik juga harus membiasakan dan melatih anak didiknya agar bertingkah laku yang baik, sopan, jujur untuk kebenaran, menghormati guru dengan penuh ta'dzim serta menghormati kedua orang tuanya.

\section{Simpulan}

Aksiologi secara sederhana berarti nilai guna, sedangkan dalam kajian filsafat, istilah aksiologi biasanya diartikan sebagai suatu bidang (filsafat) yang menyelidiki nilai-nilai (values), termasuk di dalamnya tentang tujuan memperoleh pengetahuan. Aksiologi pendidikan Islam merupakan suatu proses perubahan tingkah laku yang dilakukan melalui aktifitas yang dapat menanamkan nilai-nilai yang baik dan mulia sebagai bekal kehidupan manusia menjalani hidup yang lebih baik. Akidah adalah perkara-perkara yang wajib dibenarkan oleh hati, dan ditanamkan dalam diri, sehingga menjadi yakin dan mengikat, yang tidak pernah tersentuh oleh keragu-raguan. Nilainilai akidah dalam pendidikan Islam merupakan suatu kualitas ketauhidan/ keimanan kepada Sang Pencipta, Allah Ta'ala yang dimiliki manusia setelah dia mengenal Tuhannya yang berkaitan dengan hubungan manusia itu sendiri dengan Allah SWT.

Kecerdasan peserta didik dapat diperoleh jika lembaga pendidikan menggali

dan menyelami nilai-nilai yang diajarkan dalam Al-Qur'an dengan cara mengaktualisasikan nilai-nilai Qur'ani ke dalam pribadi anak. Proses ini membutuhkan landasan aksiologis dalam pendidikan agar pendidikan itu sendiri dapat memberikan kepuasan pada diri peserta didik akan nilai- nilai ideal yang ingin dimiliki, sehingga 
dapat hidup dengan baik dan terhindar dari nilai- nilai yang tidak diinginkan. Penerapan nilai-nilai akidah pada anak dapat dilakukan dengan cara anak dibiasakan berdiskusi tentang aspek-aspek terpenting dalam akidah yang terdiri dari: pertama, pengenalan Allah dengan cara sederhana; kedua, pengajaran tentang hukum-hukum Islam yang paling dasar; ketiga, pengajaran baca al-Qur'an; keempat, pengajaran tentang hak-hak kedua orangtua; kelima, pengenalan tokoh-tokoh teladan dalam Islam.

\section{DAFTAR PUSTAKA}

Abri, Ali. Filsafat Umum Suatu Pengantar. IAIN SUSQA, tt.

Al-Toumy Al- Syaibany, Omar Mohammad. Falsafah Pendidikan Islam. Jakarta: Bulan Bintang, 1979.

An Nahlawi, Abdurrahman. Pendidikan Islam di Rumah, Sekolah dan Masyarakat. Jakarta: Gema Insani Press, 1995.

Assegaf, Abd. Rachman. Filsafat Pendidikan Islam: Paradigma Baru Pendidikan hadhari Berbasis Integratif-Interkonektif. Yogyakarta: Rajawali, 2011.

Basyir, Azhar A. Pendidikan Agama Islam I (Aqidah). Yogyakarta: FH UII, 1995.

Daradjat, Zakiah. Ilmu Pendidikan Islam. Jakarta: Bumi Aksara, 2008.

Daudy, Ahmad. Kuliah Akidah Islam. Jakarta: Bulan Bintang, 1997.

Departemen Pendidikan dan Kebudayaan, Kamus Besar Bahasa Indonesia. Jakarta: Balai Pustaka, 1990.

Fatimah, Irma ed., Filsafat Islam. Yogyakarta: LESFI, 1992.

Fauzal Adhim, Muhammad Mendidik Anak Menuju Taklif. Yogyakarta: Pustaka Pelajar, 1996.

Fuady, M. Noor dan Ahmad Muradi, Pendidikan Akidah Berbasis Keluarga. Banjarmasin: Antasari Press, 2012.

Hidayat, Ainurrakhman. Buku Ajar Filsafat Ilmu. Pamekasan: STAIN Press, 2006.

Husin Al Munawar, Said Agil. Aktualisasi Nilai-Nilai Qur'ani dalam Sistem Pendidikan Islam, cet. II. Ciputat: Ciputat Press, 2005.

Ibn Abdul Hamid al-Atsari, Abdullah. Al-Wajiz fi 'Aqidah al-Salaf al-Shalih. Arab Saudi: Wizarah al-Syu'un al-Islamiyyah wa al-Auqaf wa al-Da'wah wa al-Irsyad, 1422.

Vol. ㄴ. ‥ 02. Qktober 2019

Jurnal Auladuna | 8 
Ibn Abdul Aziz ibn Humadah al-Jabarain, Abdullah. Mukhtashar Tashil al-Aqidah alIslamiyyah. Tt: Maktabah al-Rusyd, 1424H.

Jalaluddin, Filsafat Pendidikan Islam. Jakarta: Kalam Mulia, 2011.

Mudyaharjo, Redja. Filsafat Ilmu Pendidikan. Bandung: Remaja Rosdakarya, 2001.

Muhmidayeli, "Moralita Kependidikan: Suatu Telaah Filsafat Pendidikan Islam Tentang Arah Bangun Pendidikan Islam”, vol. 5. Al-Fikra, 2006.

Mujib, Abdul dan Yusuf Mudzakkir, Ilmu Pendidikan Islam. Jakarta: Kencana, 2008.

Mujib, Abdul et al., Ilmu Pendidikan Islam, cet. 2. Jakarta: Kencana, 2008.

Nata, Abuddin. Manajemen Pendidikan. Jakata: Kencana, 2008.

Sabiq, Sayyid. Unsur-Unsur Kekuatan dalam Islam, terj. Muhammad Abadi Rathony. Surabaya: Ahmad Nabhan, 1981.

Sadulloh, Uyoh. Pengantar Filsafat Pendidikan. Bandung: Penerbit Alfabeta CV, 2007.

Salam, Burhanuddin. Logika Materil: Filsafat Ilmu Pengetahuan. Jakarta: Reneka Cipta, 1997.

Suriasumantri S. dan Jujun, Filsafat Ilmu sebuah Pengantar Populer. Jakarta: Pustaka Sinar Harapan, 1996.

Suyudi, M. Pendidikan dalam Perspektif Al-Qur'an. Yogyakarta: 2005.

Syahridho dan Sutarman, Aliran-aliran Filsafat (tt).

Tim Penyusun Kamus, Kamus Besar Bahasa Indonesia, cet. Kedua. Jakarta: Departemen Pendidikan dan Kebudayaan, 1989. 